\title{
Graphene Functionalized Decellularized Scaffold Promotes Skin Cell Proliferation
}

Jafarkhani, Mahboubeh; Salehi, Zeinab; Bagheri, Zahra ; Aayanifard, Zahra ; Rezvan, Ali ; Doosthosseini, Hamid ; Shokrgozar, Mohammad Ali

Published in:

Canadian Journal of Chemical Engineering

Link to article, DOI:

$10.1002 /$ cjce.23588

Publication date:

2020

Document Version

Peer reviewed version

Link back to DTU Orbit

Citation (APA):

Jafarkhani, M., Salehi, Z., Bagheri, Z., Aayanifard, Z., Rezvan, A., Doosthosseini, H., \& Shokrgozar, M. A. (2020). Graphene Functionalized Decellularized Scaffold Promotes Skin Cell Proliferation. Canadian Journal of Chemical Engineering, 98(1), 62-68. https://doi.org/10.1002/cjce.23588

\section{General rights}

Copyright and moral rights for the publications made accessible in the public portal are retained by the authors and/or other copyright owners and it is a condition of accessing publications that users recognise and abide by the legal requirements associated with these rights.

- Users may download and print one copy of any publication from the public portal for the purpose of private study or research.

- You may not further distribute the material or use it for any profit-making activity or commercial gain

- You may freely distribute the URL identifying the publication in the public portal 


\title{
Graphene Functionalized Decellularized Scaffold Promotes Skin Cell Proliferation
}

\author{
Mahboubeh Jafarkhani, ${ }^{1,2}$ Zeinab Salehi, ${ }^{1, *}$ Zahra Bagheri, ${ }^{1}$ Zahra Aayanifard, ${ }^{1}$ Ali \\ Rezvan, ${ }^{1}$ Hamid Doosthosseini, ${ }^{1}$ Mohammad Ali Shokrgozar ${ }^{3}$ \\ ${ }^{1}$ School of Chemical Engineering, College of Engineering, University of Tehran, Iran \\ ${ }^{2}$ DTU Nanotech, Technical University of Denmark, Kongens. Lyngby, Region \\ Hovedstaden, Denmark \\ ${ }^{3}$ National Cell Bank of Iran, Pasteur Institute of Iran, Tehran, Iran \\ *Corresponding author email: zsalehy@ut.ac.ir
}

\begin{abstract}
An increasing number of new strategies for skin tissue engineering have been developed with the potential to mimic the biological properties of native tissue with a high degree of complexity, flexibility, and reproducibility. In this study, decellularized tissue (DT) was prepared from the bovine heart by using chemical treatments. However, the mechanical properties of the DT constructs were poorer than the extra cellular matrix of the skin tissue. To overcome this challenge, hybrid scaffolds of DT and graphene oxide (GO) were developed and the effects of the GO concentration on the morphology, pore size, porosity, mechanical strength, and water uptake capacity of the samples were evaluated. Moreover, the biocompatibility of hybrid scaffolds was studied by Live/Dead staining. The results show that a hybrid scaffold incorporating $3 \%$ graphene oxide improved the mechanical strength and cell viability by $25 \%$ in comparison to the DT scaffolds. Cell viability results confirmed that the porous scaffolds could support cell adhesion, proliferation, and cell activity for 7 days. This study provides new insight into and This article has been accepted for publication and undergone full peer review but has not been through the copyediting, typesetting, pagination and proofreading process, which may lead to differences between this version and the Version of Record. Please cite this article as doi: 10.1002/cjce.23588.
\end{abstract}

This article is protected by copyright. All rights reserved. 
opportunities for using graphene-based materials to develop biomimetic constructs for clinical applications.

KEYWORDS: decellularized tissues, biomimetic scaffolds, graphene oxide, skin tissue engineering

\section{INTRODUCTION}

About one-tenth of human body tissue is skin, which is essential for the survival and protection of internal tissues. ${ }^{[1]}$ Current treatments for healing dermal wounds continue to rely on skin transplantation. Several studies have been directed to find new strategies to replace and repair damaged skin, however, effective treatments have not yet been proposed. Various skin replacements including xenografts, autografts, and allografts have been utilized to assist in the wound healing process, however, these kinds of skin substitutes are not ideal for skin regeneration due to the immune response of the body. ${ }^{[2-5]}$ Hence, significant research and development efforts in the field of tissue engineering have been made and have led to the creation of functional skin tissue substitutes. ${ }^{[6-8]}$ The design of three-dimensional (3D) scaffolds with the biological characteristics and functions of the native extracellular matrix (ECM) is one of the most important challenges in tissue engineering. ${ }^{[9,10]}$

To develop a clinical 3D construct, the performance of decellularized tissues as biological scaffolds were evaluated. ${ }^{[11,12]}$ However, the application of decellularized allogeneic organs is limited due to the lack of donor organs. Decellularized tissues (DT) of various xenogeneic organs have been proven to have regenerative capabilities in vivo and in vitro and, consequently, have become an emerging treatment approach. Bovine cardiac tissue is not only readily available, but also has been decellularized in several studies. ${ }^{[13-15]}$ Moreover, xenogeneic decellularized cardiac tissue has an inherent vascularization capacity, which is essential for the survival of engineered tissue. ${ }^{[16]}$ These biomaterials can create an appropriate environment for cell proliferation, differentiation, migration, and gene expression. These natural scaffolds can support angiogenesis due to their notable cell affinity and their ability to provide a microenvironment similar to the extracellular matrix. ${ }^{[17]}$ Decellularized constructs have been used for skin

This article is protected by copyright. All rights reserved. 
transplantations, cosmetic surgery, and for skin defects, and the results have confirmed that they can support skin regeneration after implantation. ${ }^{[18,19]}$ Decellularized scaffolds can stimulate important biological processes such as re-epithelialization, granular tissue formation, and neovascularization at the initial stages of implantation. Therefore, decellularized scaffolds are promising constructs for clinical applications in the future. ${ }^{[20]}$ Graphene oxide (GO) is a two-dimensional material composed of tightly packed layers of sp2 carbon atoms that are arranged in a hexagonal crystal lattice. ${ }^{[21]}$ In recent years, GO has received widespread attention due to its extraordinary characteristics including biocompatibility, acceptable mechanical strength, large specific surface area, and exceptional thermal and electrical conductivity. ${ }^{[22]}$ As a result, GO has also been widely used in biological applications such as for the diagnosis of different diseases, cancer therapy, photo-thermal treatments, cell direction with electrical signals, drug delivery, and tissue engineering. ${ }^{[22-25]}$ For example, Shin et al. ${ }^{[26]}$ used GO in gelatin methacryloyl (GelMA) scaffolds to engineer myocardial tissues. They reported that the addition of reduced GO (rGO) to GelMA substantially increased the biological activities and mechanical properties of the GelMA.

Furthermore, cells cultured on hybrid scaffolds of GelMA and rGO resulted in higher cellular viability and improved proliferation, in comparison with cells seeded on GelMA scaffolds without rGO. More recently, Zhang et al. ${ }^{[27]}$ fabricated hybrid nano-fibrous scaffolds of polyvinyl alcohol (PVA) and GO scaffolds with different contents of GO via an electrospinning technique. They reported that the fibres' diameters decreased from 230 to $166 \mathrm{~nm}$ when the GO content increased from 0 to $1 \mathrm{wt} \%$. Furthermore, their results confirmed that the GO improved the mechanical strength of the samples and improved the proliferation and adhesion of the NIH 3T3 fibroblasts on the scaffolds.

In this study, we fabricated novel and porous scaffolds made of DT and GO using a freeze-drying technique and studied their surface morphology and physicochemical and mechanical properties. Skin cell lines (NIH 3T3) were cultured on the scaffold's surface and the applicability and suitability of these novel scaffolds as supporting materials for tissue engineering was studied.

This article is protected by copyright. All rights reserved. 


\section{MATERIALS AND METHODS}

Sulfuric acid $\left(\mathrm{H}_{2} \mathrm{SO}_{4}\right)$, phosphoric acid $\left(\mathrm{H}_{3} \mathrm{PO}_{4}\right)$, potassium permanganate $\left(\mathrm{KMnO}_{4}\right)$, sodium dodecyl sulfate (SDS), and hematoxylin-eosin were bought from Sigma-Aldrich. 1-Ethyl-3-(3-dimethylaminopropyl)carbodiimide (EDC) and N-Hydroxysuccinimide (NHS), used to crosslink the samples, were obtained from Merck. Culture media (RPMI), fetal bovine serum (FBS), and phosphate buffered saline (PBS) were also obtained from Merck. Trypsin-EDTA, penicillin-streptomycin, and lysozyme were purchased from Gibco.

\section{Preparation of GO}

Graphene oxide (GO) was produced using natural graphite powder via the modified Hummers' method. ${ }^{[27]}$ Briefly, $1 \mathrm{~g}$ of graphite flakes was suspended in a 9:1 mixture of concentrated $\mathrm{H}_{2} \mathrm{SO}_{4} / \mathrm{H}_{3} \mathrm{PO}_{4}$ and stirred for $30 \mathrm{~min}$. Then, $6 \mathrm{~g}$ of $\mathrm{KMnO}_{4}$ was slowly added to the mixture. This was heated to $50{ }^{\circ} \mathrm{C}$ and agitated for $24 \mathrm{~h}$. Then, the temperature of the mixture was reduced to $25^{\circ} \mathrm{C}$ and, subsequently, $200 \mathrm{~mL}$ of distilled water was added to it. For further oxidation, the suspension was treated with $5 \mathrm{~mL}$ of 30 $\% \mathrm{H}_{2} \mathrm{O}_{2}$. The mixture was centrifuged and washed twice with hydrochloric acid (1 M) and was finally washed with deionized water a few times until the $\mathrm{pH}$ was neutralized. The characterization study of the GO was presented in our previous study. ${ }^{[27]}$

\section{Preparation of Decellularized Tissue (DT)}

The decellularization of the bovine heart tissue was performed using an enzymatic detergent, based on Seif-Naraghi et al.'s ${ }^{[28]}$ protocol. Briefly, the thin sheets of bovine native cardiac tissue were cut and washed with PBS for $2 \mathrm{~h}$ and then submerged in an SDS solution (1 wt\%) and mixed for $24 \mathrm{~h}$. The SDS solution was refreshed daily until a clear solution was obtained. In the next step, the white tissues were washed in sterile PBS overnight and lyophilized (Christ, Alpha 1-2 LD) for $24 \mathrm{~h}$ at $-50{ }^{\circ} \mathrm{C}$.

This article is protected by copyright. All rights reserved. 


\section{Preparation of Porous Scaffolds of DT and GO}

DT powder was dissolved in $1 \%(\mathrm{v} / \mathrm{v})$ hydrochloric acid containing $1 \%$ pepsin. $\mathrm{NaOH}$ (1 M) was added to neutralize the remaining hydrochloric acid. Different volume percentages of the GO solution $(0,1,3$, and $5 \%)$ were then added to the DT at $40{ }^{\circ} \mathrm{C}$ for

at least $6 \mathrm{~h}$. Subsequently, the hybrid solution of DT and GO was cast into a 24-well plate and lyophilized at $-50{ }^{\circ} \mathrm{C}$ for $24 \mathrm{~h}$. The samples were then all immersed in EDC/NHS for $2 \mathrm{~h}$ for the crosslinking reaction between two functional groups of DT and GO to occur. The covalent bonding between the DT and GO was performed in the presence of EDC/NHS. The mechanism is shown below (Figure 1), whereby carboxyl groups ($\mathrm{COOH})$ of the GO were activated by EDC and reacted with amine groups $\left(-\mathrm{NH}_{2}\right)$ of the DT. Finally, the DT/GO constructs were washed with deionized water to eliminate excess EDC/NHS residues and salt deposits.

\section{Evaluation of the Decellularization Process}

Decellularized tissues were fixed in a neutral buffered formalin solution containing $10 \%$ PBS (pH 7.4) at $25^{\circ} \mathrm{C}$ for $24 \mathrm{~h}$. The samples were then immersed in deionized water, inserted in paraffin, and sliced into thin sections. Hematoxylin-eosin staining was used to detect cell nuclei in the samples via a light microscope (BX51, Olympus). ${ }^{[29]}$

\section{Fourier Transform Infrared (FTIR) Spectroscopy}

The variation in the chemical structure of the DT/GO constructs were studied by Fourier transform infrared spectrometry (FTIR, Nicolet 560, U.S.A.). Three samples for each group were analyzed.

\section{Morphological Characterization and Mechanical Properties}

The surface morphology of the DT/GO porous scaffolds was investigated under a scanning electron microscope (SEM) (JEOL JSM-5600LV, Japan) with an enhanced voltage of $15 \mathrm{kV}$. First, the dried construct's surface was covered with gold to increase the electrical conductivity of the samples. A minimum of 20 pores were selected arbitrarily for each sample and every pore size was determined by Image Analyzer 
software (Image J 1.44p). The average porosity of the porous scaffolds was measured using a liquid displacement approach. ${ }^{[30]}$

To study mechanical properties of DT/GO scaffolds, they were cut to suitable dimensions (cylindrical shapes with a diameter of $15.6 \mathrm{~mm}$ and a height of $1 \mathrm{~cm}$ ) and their elasticity was measured using a tension and compression testing machine (Instron4505, USA) with a $50 \mathrm{~N}$ load cell at $25^{\circ} \mathrm{C}$ according to ASTM standards. The elasticity modulus was determined as the slope of the linear region of the stress-strain curve within the range of strain under $10 \%$.

\section{Swelling Study}

The porous scaffolds' swelling behaviour was calculated from experimental measurements of weight using Equation (1). First, the weight of the dry constructs was measured, and the samples were then immersed in a PBS solution ( $\mathrm{pH} 7.4)$ for different time intervals and were weighed again to study the water uptake ability of the scaffolds versus time:

Swelling ratio $(\%)=\left[\left(\mathrm{W}_{\mathrm{s}}-\mathrm{W}_{\mathrm{d}}\right) / \mathrm{W}_{\mathrm{d}}\right] \times 100(1)$

where $W_{s}$ and $W_{d}$ are the weights of the swollen and dry samples, respectively. ${ }^{[31]}$ All of the experiments were performed three times and average values were obtained.

\section{Cell Culture Study}

Fibroblasts cell line (NIH 3T3) was purchased from Sigma Aldrich. NIH 3T3 were cultured in RPMI media containing $10 \%$ FBS (v/v) and $1 \%(\mathrm{v} / \mathrm{v})$ penicillin/streptomycin. Cells were maintained in an incubator at $37^{\circ} \mathrm{C}$ in a humidified environment containing $5 \%$ carbon dioxide. ${ }^{[32]}$ The scaffolds were cleaned using ethanol and UV and, subsequently, a $5 \mu \mathrm{L}$ suspension of NIH 3T3 ( $5 \times 10^{4}$ cells) was seeded onto the scaffold surface $\left(10 \times 10 \times 2 \mathrm{~mm}^{3}\right)$. After $1 \mathrm{~h}$, a $5 \mu \mathrm{L}$ of RPMI medium was added to the cell-seeded constructs. After an additional hour, the scaffolds were placed in adequate culture media. The culture media was changed every 2 days.

This article is protected by copyright. All rights reserved. 


\section{Cell Viability Analysis}

The porous scaffolds ( $3 \pm 0.5 \mathrm{~cm}^{2} / \mathrm{mL}$ of culture medium) were sterilized and placed in 96-well plates and incubated at $37^{\circ} \mathrm{C}$ in RPMI media without FBS for 1 and 7 days. In the following step, $1 \times 10^{4}$ cells/mL of NIH 3T3s were seeded on each group of the samples (for each group 6 repetitions were considered). Cell viability on the biomimetic scaffolds was investigated utilizing a Live/Dead viability kit (Abcam, UK) containing calcein-AM and ethidium homodimer-1 (EthD-1). After 7 days of cell culture, the samples were incubated for 30 min with a Live/Dead solution kit and images were obtained using a confocal microscope (Zeiss LSM 720). ${ }^{[34]}$

\section{Statistical Analysis}

All data is presented as the mean value of at least three samples \pm standard deviation (SD) for repetitive tests. A one-way analysis of variance (ANOVA) statistical analysis was carried out to assess the statistical significance of the results between groups and the differences for values of $\mathrm{p}<0.05$ were considered statistically significant.

\section{RESULTS AND DISCUSSION}

Using chemical and enzymatic agents, the bovine heart was decellularized, and to confirm the decellularization process, histological staining was used (Figures 2a and b). The results of the $\mathrm{H} \& \mathrm{E}$ staining of the native heart and the DT approved the accuracy of decellularization process because no nuclei were observed in the microscopic images of the DT samples.

\section{FTIR Spectroscopy}

FTIR spectroscopy provides an analytical tool to study the chemical interaction between two components of the DT/GO scaffolds and the results are presented in Figure 3. It shows the FTIR spectrum of pure DT, GO, and DT/GO 3 \% scaffolds. As anticipated, the DT/GO spectrum indicated characteristic bands of both the DT and GO. ${ }^{[35,36]}$ For the DT scaffolds, an absorption peak near 1570 and $3435 \mathrm{~cm}^{-1}$ consistent with the bending and extending band of N-H was observed. ${ }^{[35]}$ The FTIR spectrum of GO shows stretching 
vibrations of C-O bonds near 1050 and $1366 \mathrm{~cm}^{-1}$ as well as epoxy C-O bonds at 1227 $\mathrm{cm}^{-1}$. Furthermore, the intensity at 1627,1707 , and $3415 \mathrm{~cm}^{-1}$ can be attributed to $\mathrm{C}=\mathrm{C}$ (aromatic), carbonyl and O-H stretching bonds, respectively. The FTIR spectrum of DT/GO 3 \% scaffolds demonstrated a remarkable decrease in the intensity of the $\mathrm{N}-\mathrm{H}$ (at $1630 \mathrm{~cm}^{-1}$ ) and $\mathrm{C}=\mathrm{O}$ (at $1690 \mathrm{~cm}^{-1}$ ) peaks in comparison with the FTIR graphs of the pure DT and GO, respectively. This may demonstrate the weak reaction between the amino groups of the DT and the carboxyl group in the GO during the cross-linking process by the EDC/NHS, as reported in another study, ${ }^{[37]}$ since the EDC-NHS compound is a crosslinking agent used to link carboxyl (-COOH) or phosphate groups to amines $\left(-\mathrm{NH}_{2}\right)$.

\section{Morphological Characterization and Mechanical Properties}

The results of the morphological observations of the porous scaffolds are shown in Figure 4a. The SEM images of all of the samples indicated porous structures with interconnected pores. This physical feature aids the delivery of nutrients and oxygen to the cells as well as the efficient removal of waste. Furthermore, it can be seen that the addition of GO has an important influence on the pore structure of the porous scaffolds. The GO addition decreased the average pore size of the DT/GO scaffolds because the GO particles occupy a part of the pores volume in the samples. Table 1 presents the effects of the GO content on the porosity and average pore size of the scaffolds.

The samples with higher GO contents were found to have less interconnected pores in comparison to pure DT scaffolds, due to incompetent mixing of the two components. ${ }^{\text {[35] }}$

The cell behaviour also closely depends on the scaffolds' stiffness. Therefore, we studied the mechanical properties of the porous substrates next. The mechanical strength of the DT/GO samples are listed in Table 1. It is well known that cells are exposed to different mechanical forces in in vivo conditions. Thus, the biomimetic scaffolds should provide adequate mechanical strength to resist the effective forces in the body, maintain their structural stability, and direct the cells’ behaviour. Conversely, the highly reinforced structures achieved by increasing the GO concentration may obstruct cell proliferation, as their dense pore structure limits permeability. ${ }^{[38]}$

This article is protected by copyright. All rights reserved. 
From Table 1, the maximum elastic modulus ( $12.7 \pm 2.5 \mathrm{kPa})$ was obtained from samples containing $5 \% \mathrm{GO}$; this is due to partial covalent binding between the functional group of DT and GO, which was confirmed by the FTIR study (Figure 3). Another reason for this is that the pores fill with additional GO content, as shown in the SEM observation (Figures 4b, c, and d). Table 1 shows that the minimum Young modulus ( $8.4 \pm 1.3 \mathrm{kPa})$ was observed in samples without GO. It can be concluded that the GO addition and chemical crosslinking treatment increase the mechanical strength of the scaffolds. The results in Table 1 show that the DT scaffolds and the samples containing $1 \%$ GO have similar values for the Young modulus and equal pore sizes. Thus, the lower mechanical strength of these samples is related to the lack of strong-chemical binding and the high value of porosity and large pore size. The improvement in the mechanical strength using GO was also reported in other literature. ${ }^{[39-41]}$ For example, Sayyar et al. ${ }^{[40]}$ reported that the addition of $3 \mathrm{wt} \%$ GO to the chitosan films increased the Young modulus to $130 \%$. This is the result of the development of non-porous films and the presence of strong chemical interactions between the GO and chitosan.

\section{Swelling Rate}

The ability to uptake water is a main feature of scaffolds for biomedical applications due to its effect on the capacity for the exchange of nutrients and waste products. ${ }^{[42]}$ The results of water absorption testing for different scaffolds are shown in Figure 5. It can be seen that the percentage of the water absorption of all of the samples increased dramatically during the first hour of the test and reached a steady (maximum swelling) value after $2 \mathrm{~h}$. In general, the hybrid constructs showed a lower water uptake ability the pure DT. The DT scaffolds without GO showed the highest water uptake percentage ( $\sim 50$ $\%$ ), whereas samples with $5 \%$ GO had a water uptake percentage of around half of that. ${ }^{[43]}$ This can be attributed to the different natures of the DT scaffolds and the GO with regards to the hydrophilic groups that are more prevalent in the DT scaffolds. Moreover, a reduction in the swelling versus the GO addition is a result of the changes in the microstructure of the porous scaffolds that were occupied by GO particles. Therefore, the samples containing more GO, which consequently have lower porosity, can absorb less water.

This article is protected by copyright. All rights reserved. 
It is well known that the chemical and structural properties of the scaffold significantly impact cell viability. Pore size should not only provide an adequate surface area for cell attachment but also facilitate cell migration. Moreover, the cytocompatibility of the scaffolds composite is another vital factor in order to maintain viable cells. ${ }^{[44]}$ Therefore, we studied cell viability on the DT/GO scaffolds to assay the effect of chemical composition and morphology on the skin cells.

\section{Viability Analysis}

We evaluated cell viability on the porous scaffolds at day 1 and 7 to study the samples biocompatibility capacity. Figure 6a indicates florescent images of the stained NIH 3T3 by calcein-AM/4 $\mu \mathrm{M}$ EthD-1 on the scaffolds containing various weight percentages of GO. As Figure 6a shows, the number of live cells (green) for all of samples is approximately equal after $24 \mathrm{~h}$. However, after 7 days the dead cells (red) increased in all of the specimens. This could be the result of a 2D cell culture and the lack of an appropriate surface for cell attachment and proliferation. Furthermore, it can be seen that the dead cells in the control (GO $0 \%$ ) samples and the DT/GO $5 \%$ samples increased significantly. This may demonstrate the insufficient mechanical strength of the control samples to maintain their structure and also demonstrate the toxic effects of a higher concentration of GO (5 wt\%). These results suggest that a low concentration of GO, when used as a filler to achieve stronger scaffolds, was safe and nontoxic at weight percentages $<3$. Figures $6 \mathrm{~b}$, c, and d show the quantitative results of the Live/Dead assay, which were obtained by counting the average number of the total and live cells (by ImageJ software ) in at least 6 different sections of each group of samples and by calculating the cell viability percentage. It can be found that a GO concentration of $3 \%$ leads to higher cell viability (up to $25 \%$ ) in comparison to pure DT. Consequently, this was selected as the optimized concentration of GO in the scaffold for the NIH 3T3 cell culture to avoid the potential for cytotoxicity. These results are in agreement with previous studies that have demonstrated that both DT constructs and GO are biocompatible and biodegradable. ${ }^{[19,26,27,43]}$

This article is protected by copyright. All rights reserved. 


\section{CONCLUSION}

In this study, a novel biomaterial was developed by incorporating $\mathrm{GO}$ as a filler material in the scaffolds' bulk via a freeze-drying technique. A significantly higher mechanical strength was observed in the scaffolds with an increased GO content from 0-5 \% wt. in the composite. The results demonstrated that the DT/GO 3 \% scaffolds with improved mechanical properties supported the growth and viability of the NIH 3T3 cells in vitro. It has been shown herein that DT/GO 3 \% could be a promising scaffold with significant potential for applications in skin tissue engineering.

\section{REFERENCES}

[1] C. Zhu, C. Wang, R. Chen, C. Ru, A Novel Composite and Suspended Nanofibrous Scaffold for Skin Tissue Engineering, Springer, Singapore 2018.

[2] N. Bhardwaj, D. Chouhan, B. B. Mandal, "3D Functional Scaffolds for Skin Tissue Engineering," Functional 3D Tissue Engineering Scaffolds, $1^{\mathrm{St}}$ edition, Y. Deng, J. Kuiper, Eds., Woodhead Publishing, Cambridge 2018, p. 345.

[3] E. Catalano, A. Cochis, E. Varoni, L. Rimondini, B. Azzimonti, J. Artif. Organs 2013, 16, 397.

[4] J. R. Yu, J. Navarro, J. C. Coburn, B. Mahadik, J. Molnar, J. H. Holmes IV, A. J. Nam, J. P. Fisher, Adv. Healthc. Mater. 2019, 8, 1801471.

[5] L. Chung, D. R. Maestas, F. Housseau, J. H. Elisseeff, Adv. Drug Deliver. Rev. 2017, 114, 184.

[6] S. H. Mathes, C. N. Parker, "Requirements of Skin Tissue Models for High-Throughput Screening," Skin Tissue Models for Regenerative Medicine, A. Marques, R. Reis, R. Pirraco, M. Cerqueira, Eds., Academic Press, Cambridge 2018, p. 421.

[7] O. Kashpur, A. Smith, N. Mukhamedshina, J. Baskin, Y. Shamis, K. Hewitt, B. Gerami-Naini, J. A. Garlick, "Induced Pluripotent Stem Cells to 
Generate Skin Tissue Models," Skin Tissue Models for Regenerative Medicine, $1^{\mathrm{St}}$ edition A. Marques, R.Reis, R. Pirraco, M. Cerqueira, Eds., Academic Press, Cambridge 2018, p. 399.

[8] S. P. Tarassoli, Z. M. Jessop, A. Al-Sabah, N. Gao, S. Whitaker, S. Doak, I. S. Whitaker, J. Plast. Reconstr. Aes. 2017, 71, 615.

[9] S. J. Lee, J. J. Yoo, A. Atala, "Biomaterials and Tissue Engineering," Clinical Regenerative Medicine in Urology, $1^{\text {St }}$ edition, B. Kim, Ed., Springer New York 2018, p. 17.

[10] A.-V. Do, R. Smith, T. M. Acri, S. M. Geary, A. K. Salem, "3D printing technologies for 3D scaffold engineering," Functional 3D Tissue Engineering Scaffolds, $1^{\text {St }}$ edition, Y. Deng, J. Kuiper, Eds., Woodhead Publishing, Cambridge 2018, p. 203.

[11] E. Taylan, K. Oktay, Application of Decellularized Tissue Scaffolds in Ovarian Tissue Transplantation, Decellularized Scaffolds and Organogenesis, $1^{\text {St }}$ edition, K. Turksen, Ed., Humana Press, New York 2017, p. 1.

[12] Y. Zhang, Y. Zhou, X. Zhou, B. Zhao, J. Chai, H. Liu, Y. Zheng, J. Wang, Y. Wang, Y. Zhao, Int. J. Nanomed. 2017, 12, 1441.

[13] Z. Z. Liu, M. L. Wong, L. G. Griffith, Sci. Rep.-UK 2016, 6, 37089.

[14] A. C. Gonçalves, L. G. Griffiths, R. V. Anthony, E. C. Orton, J. Heart Valve Dis. 2005, 14, 212.

[15] N. Li, Y. Li, D. Gong, C. Xia, X. Liu, Z. Xu, Interact. Cardiov. Th. 2018, 26, 768.

[16] N. W. Guldner, I. Jasmund, H. Zimmermann, M. Heinlein, B. Girndt, V. Meier, F. Flüß, D. Rohde, A. Gebert, H. H. Sievers, Circulation 2009, 119, 1653. P. Lei, H. You, S. T. Andreadis, Bioengineered Skin Substitutes, Humana 
Press, Totowa 2013.

[18] M. T. Wolf, K. A. Daly, E. P. Brennan-Pierce, S. A. Johnson, C. A. Carruthers, A. D’Amore, S. P. Nagarkar, S. S. Velankar, S. F. Badylak, Biomaterials 2012, 33, 7028.

[19] Y. Yu, A. Alkhawaji, Y. Ding, J. Mei, Oncotarget 2016, 7, 58671.

[20] D. M. Hoganson, E. M. O’Doherty, G. E. Owens, D. O. Harilal, S. M. Goldman, C. M. Bowley, C. M. Neville, R. T. Kronengold, J. P. Vacanti, Biomaterials 2010, 31, 6730.

[21] D. Li, R. B. Kaner, Science 2008, 320, 1170.

[22] S. Goenka, V. Sant, S. Sant, J. Control. Release 2014, 173, 75.

[23] H. Y. Mao, S. Laurent, W. Chen, O. Akhavan, M. Imani, A. A. Ashkarran, M. Mahmoudi, Chem. Rev. 2013, 113, 3407.

[24] M. Kakran, L. Li, Key Eng. Mater. 2012, 508, 76.

[25] X.-P. He, X.-L. Hu, T. D. James, J. Yoon, H. Tian, Chem. Soc. Rev. 2017, $46,6687$.

[26] S. R. Shin, C. Zihlmann, M. Akbari, P. Assawes, L. Cheung, K. Zhang, V. Manoharan, Y. S. Zhang, M. Yüksekkaya, K. Wan, M. Nikkhah, M. R. Dokmeci, X. S. Tang, A. Khademhosseini, Small 2016, 12, 3677.

[27] Q. Zhang, Q. Du, Y. Zhao, F. Chen, Z. Wang, Y. Zhang, H. Ni, H. Deng, Y. Li, Y. Chen, RSC Adv. 2017, 7, 28826.

[28] S. B. Seif-Naraghi, M. A. Salvatore, P. J. Schup-Magoffin, D. P. Hu, K. L. Christman, Tissue Eng. Pt. A 2010, 16, 2017.

[29] S. Rajabi-Zeleti, S. Jalili-Firoozinezhad, M. Azarnia, F. Khayyatan, S. Vahdat, S. Nikeghbalian, A. Khademhosseini, H. Baharvand, N. Aghdami, 
Biomaterials 2014, 35, 970.

[30] J. Guan, K. L. Fujimoto, M. S. Sacks, W. R. Wagner, Biomaterials 2005, 26, 3961.

[31] M. Jafarkhani, A. Fazlali, F. Moztarzadeh, Z. Moztarzadeh, M. Mozafari, Ind. Eng. Chem. Res. 2012, 51, 9241.

[32] S. Neuss, I. Blomenkamp, R. Stainforth, D. Boltersdorf, M. Jansen, N. Butz, A. Perez-Bouza, R. Knüchel, Biomaterials 2009, 30, 1697.

[33] L. Wang, J. P. Stegemann, Biomaterials 2010, 31, 3976.

[34] H. Kim, J. Kim, R. Koh, J. Shim, J. Lee, ACS Biomater. Sci. Eng. 2017, 3, 2470 .

[35] B. Nasiri, S. Mashayekhan, Biologicals 2017, 48, 39.

[36] M. K. Satapathy, W. H. Chiang, E. Y. Chuang, Ch.-H. Chen, J. L. Liao, H. N. Huang, PeerJ 2017, 5, 3498.

[37] S. Kang, J. B. Park, T. J. Lee, S. Ryu, S. H. Bhang, W. G. La, M. K. Noh, B. H. Hong, B. S. Kim, Carbon 2015, 83, 162.

[38] S. R. Shin, B. Aghaei-Ghareh-Bolagh, T. T. Dang, S. N. Topkaya, X. Gao, S. Y. Yang, S. M. Jung, J. H. Oh, M. R. Dokmeci, X. S. Tang, A. Khademhosseini, Adv. Mater. 2013, 25, 6385.

[39] S. R. Shin, B. A. Ghareh-Bolagh, X. Gao, M. Nikkhah, S. M. Jung, A. Dolatshahi-Pirouz, S. B. Kim, S. M. Kim, M. R. Dokmeci, X. (Shirley) Tang, A. Khademhosseini, Adv. Funct. Mater. 2014, 24, 6136.

[40] S. Sayyar, E. Murray, B. C. Thompson, J. Chung, D. L. Officer, S. Gambhir, G. M. Spinks, G. G. Wallace, J. Mater. Chem. B 2015, 3, 481.

[41] G. Lia, Y. Zhaoa L. Zhanga, M. Gaoa, Y. Konga,Y. Yanga, Colloid. Surface 
B 2016, 143, 547.

[42] Z. Peng, Z. Peng, Y. Shen, Polym.-Plast. Technol. 2011, 50, 1160.

[43] B. Mendoza-Novelo, J. V. Cauich-Rodriguez, Biomaterials Physics and Chemistry, 1st edition R. Pignatello, Ed., InTechOpen, London 2011.

[44] F. J. O’Brien, B. A. Harley, I. V Yannas, L. Gibson, Biomaterials 2004, 25, 1077.

\section{Figures}

Figure 1. A schematic of the chemical reaction between DT and GO in the presence of EDC/NHS.

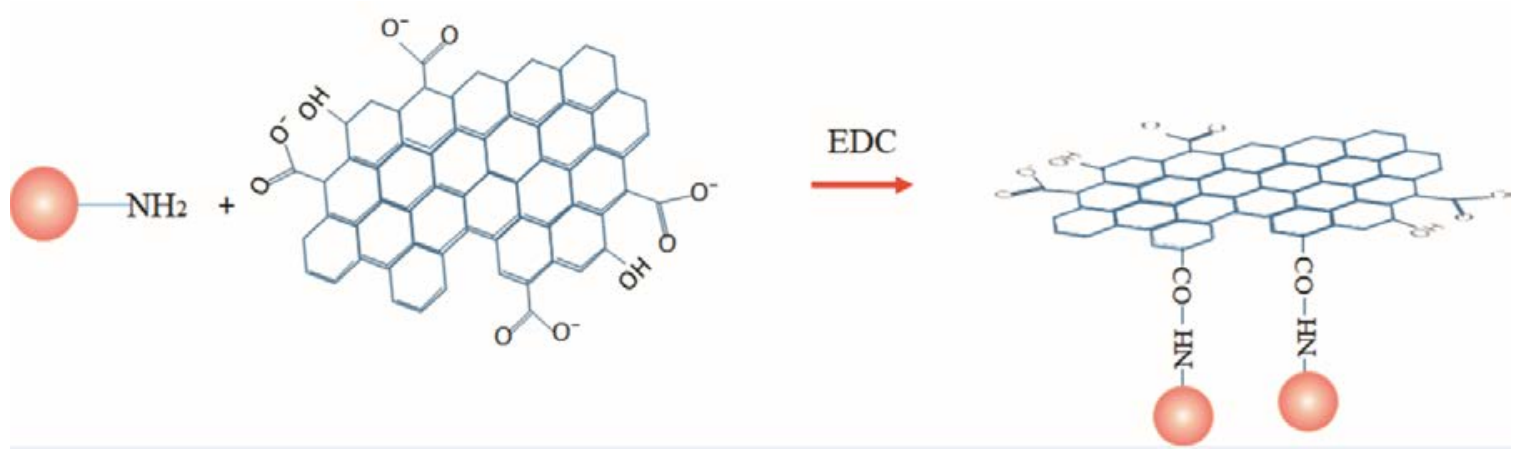

Figure 2. Histological staining for the characterization of bovine heart tissue (control) and DT. H \& E staining: a) control; and b) acellular sample.
A)
B)

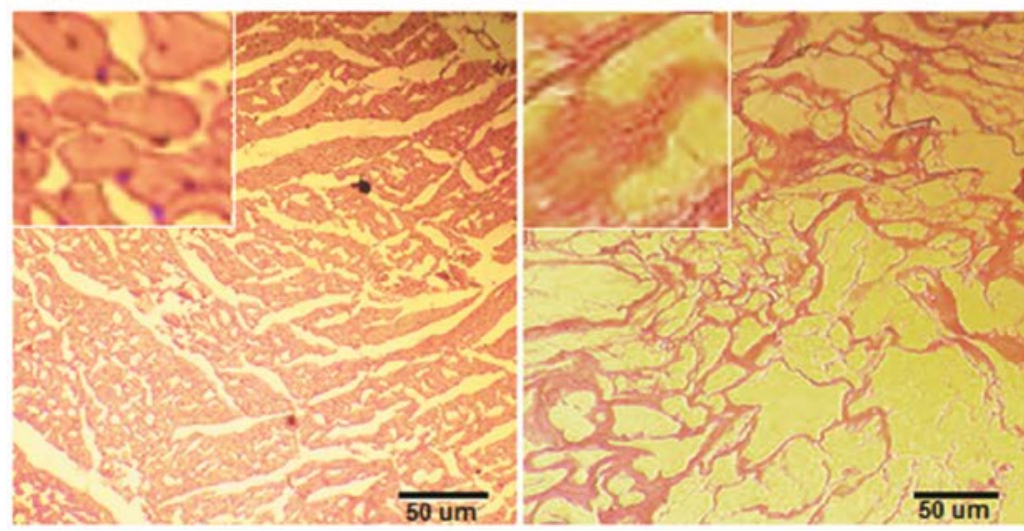

This article is protected by copyright. All rights reserved. 
Figure 3. FTIR spectra of the pure DT, GO, and DT/GO 3 \% hybrid scaffolds.

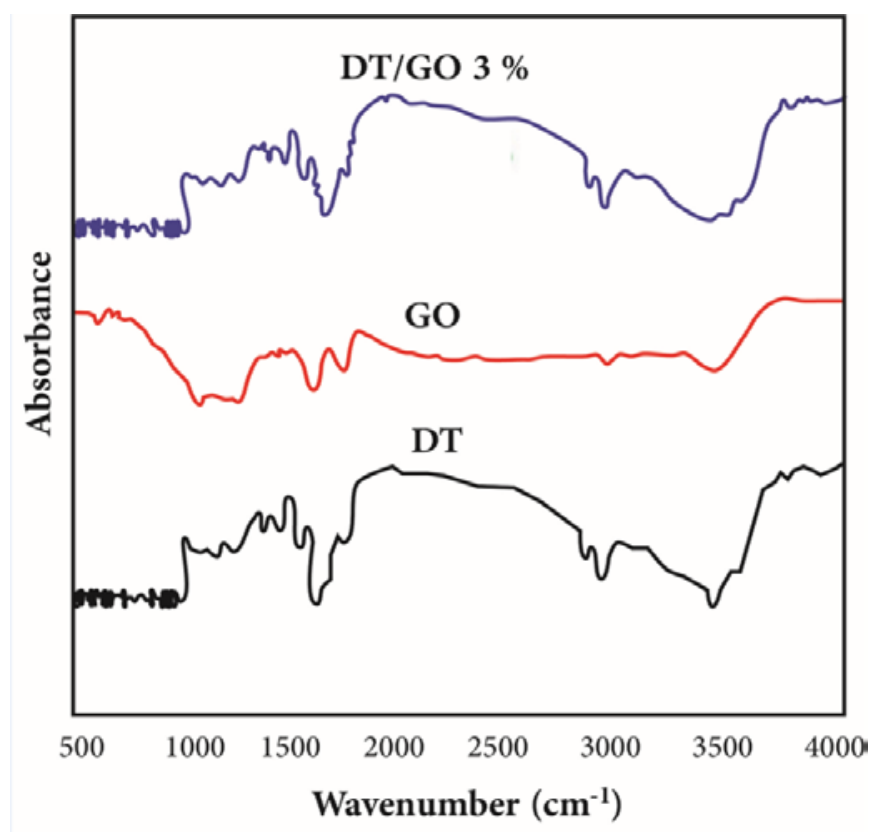

Figure 4. Macroscopic images of a) the porous scaffolds and the effect of b) 0 , c) 3, and d) $5 \%$ GO content on the scaffold microstructure.

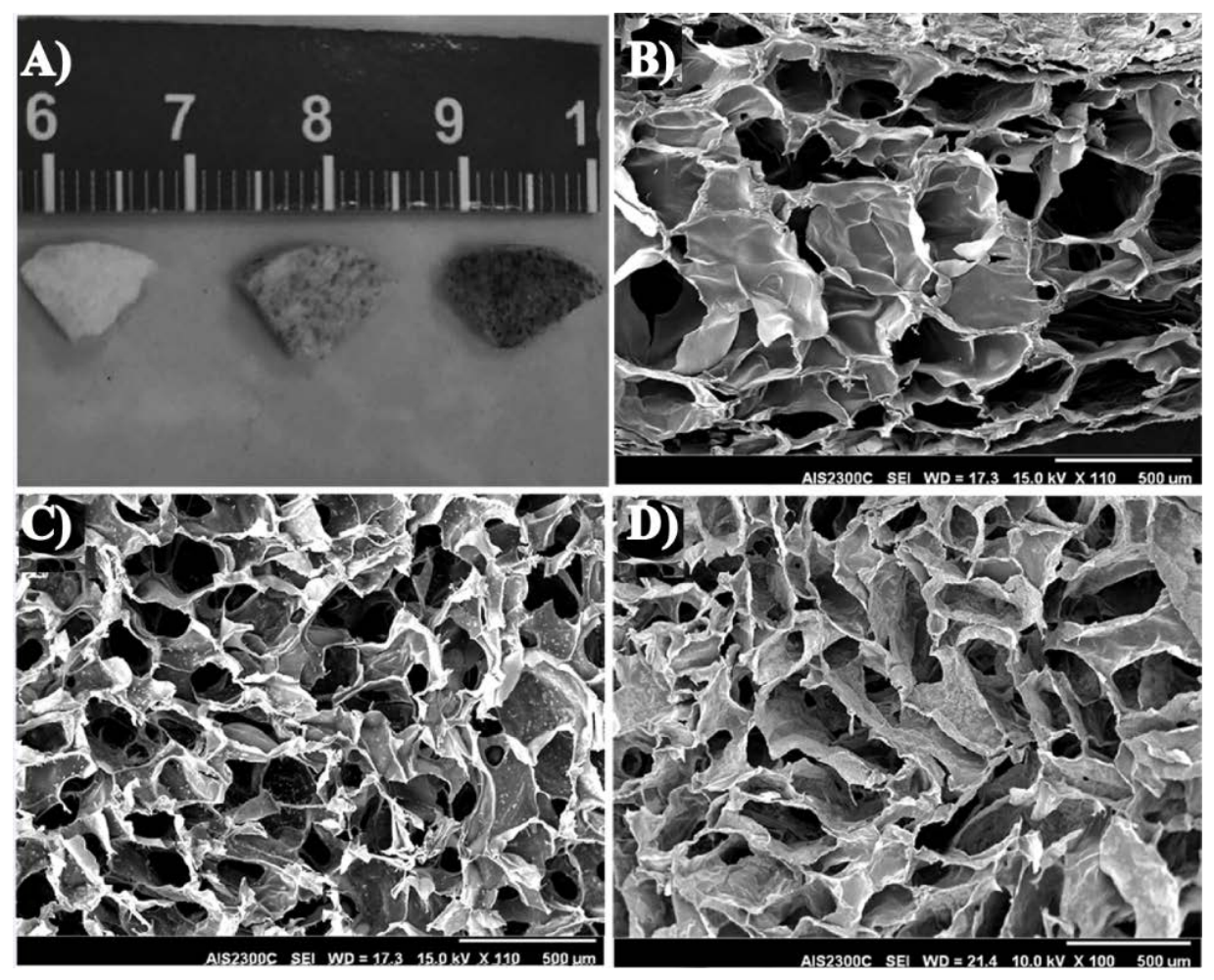

This article is protected by copyright. All rights reserved. 
Figure 5. Time dependence of water uptake of the porous scaffolds in PBS at $37^{\circ} \mathrm{C}$.

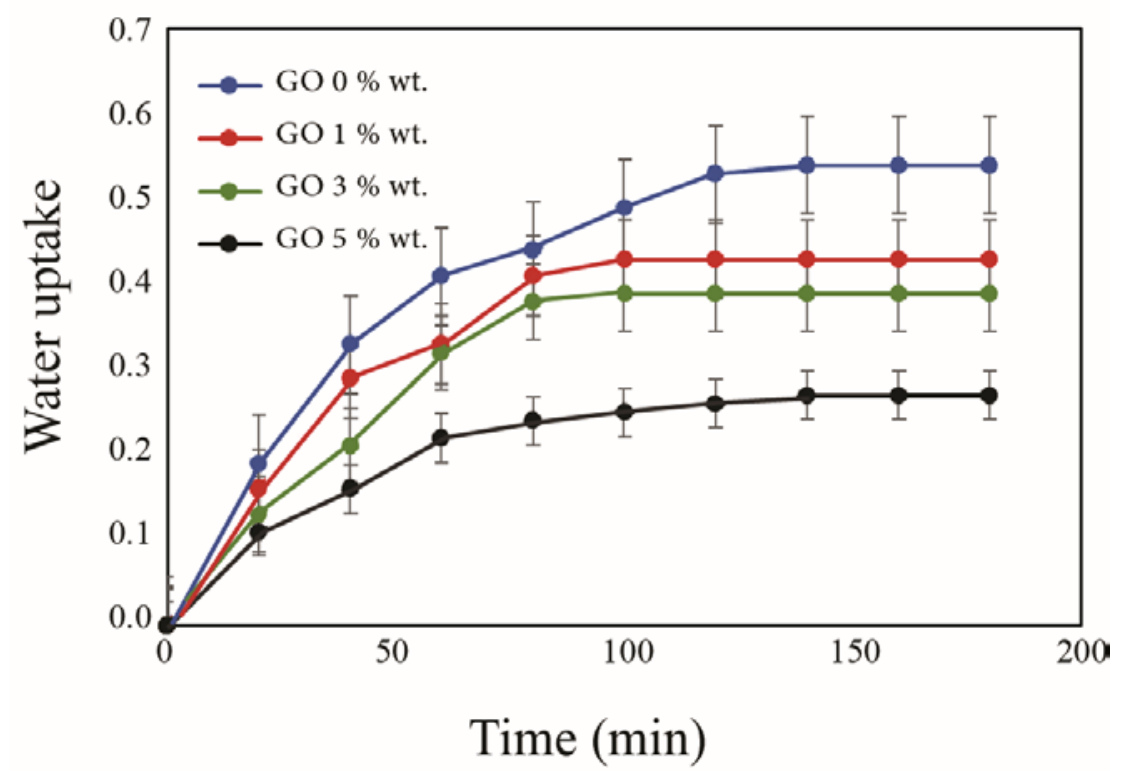

Figure 6. a) Florescent images of the Live/Dead staining of NIH 3T3 on DT/GO scaffolds with GO weight percentage of $0,1,3$, and 5 (scale bar $=100 \mu \mathrm{m}$ ); b) The quantitative results of the Live/Dead analysis; c) The average of total cells and live cells; and d) Cell viability $(\%)(* \mathrm{P}<0.05)$.

A)

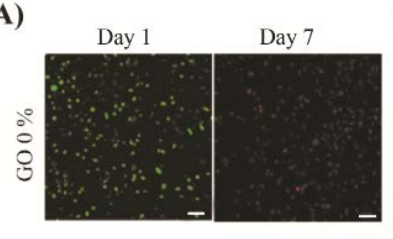

B)
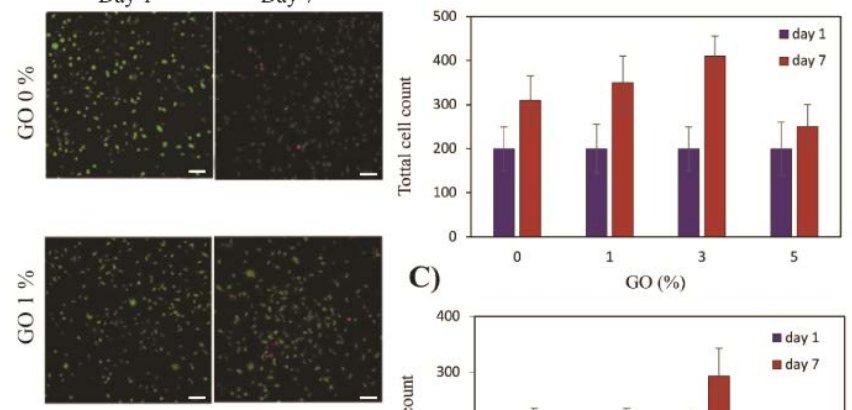

C)

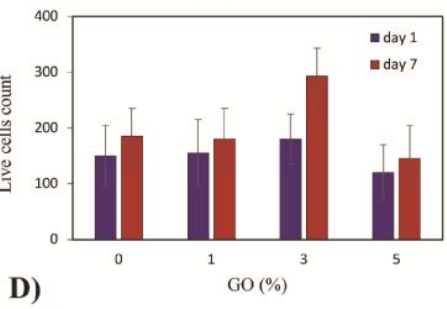

D)

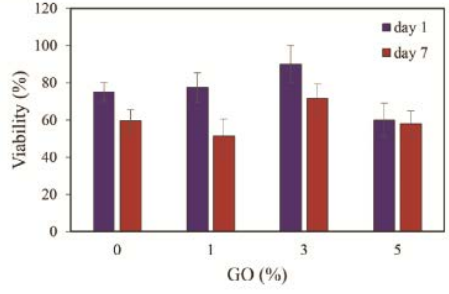

This article is protected by copyright. All rights reserved. 
Table 1: The physical properties of the DT/GO scaffolds (mean $\pm \mathrm{SD}$ ).

\begin{tabular}{llll} 
GO content & Average pore size & Porosity $\mathbf{( \% )}$ & $\begin{array}{l}\text { Young modulus } \\
\mathbf{( k P a )}\end{array}$ \\
$\mathbf{( W t} \%)$ & $(\boldsymbol{\mu m})$ & $78 \pm 12$ & $8.45 \pm 1.3$ \\
\hline $\mathbf{0}$ & $305-350$ & $71 \pm 15$ & $8.66 \pm 2.2$ \\
$\mathbf{1}$ & $280-310$ & & $10.18 \pm 1.77^{*}$ \\
$\mathbf{3}$ & & $51 \pm 11^{*}$ & $12.75 \pm 2.5^{*}$ \\
\hline
\end{tabular}

*The differences for values of $\mathrm{p}<0.05$ were considered statistically significant.

This article is protected by copyright. All rights reserved. 